\title{
Comment on the Article "Reduction of Carbon Dioxide to Carbon Nanostructures in Molten Salt: The Effect of Electrolyte Composition" by S. Abbasloo, M. Ojaghi-Ilkhchi, and M. Mozammel
}

\author{
CARSTEN SCHWANDT ${ }^{1,2}$ \\ 1.-Department of Materials Science and Metallurgy, University of Nizwa, 616 Birkat Al Mouz, \\ Nizwa, Oman. 2.-e-mail: carsten@unizwa.edu.om
}

A recent publication by Abbasloo et al. ${ }^{1}$ presents a study on the formation of nano-structured carbon in a molten salt electrolytic cell in which gaseous $\mathrm{CO}_{2}$ is fed into a melt of $\mathrm{CaCl}_{2}$ and electrolyzed under the influence of an external voltage. This is a timely and worthwhile research topic, and it is commendable that the authors highlight the attractive possibilities this area of materials processing can offer, despite its niche existence and its inherent experimental challenges. Unfortunately, however, the discussion of the results obtained in that study is based on a range of fundamental flaws, and it is therefore deemed necessary to address these here to prevent the reader from adopting incorrect ideas about this research area.

Figure 1 is a sketch of the experimental set-up employed in Abbasloo et al.'s study. The electrolytic cell comprised three key components, a melt of $\mathrm{CaCl}_{2}$ kept at $850^{\circ} \mathrm{C}$, a cathode of stainless steel that also served as the feeding tube for $\mathrm{CO}_{2}$ gas, and an anode of graphite. The external voltage was set at $3.0 \mathrm{~V}$ and applied for $120 \mathrm{~min}$, whereafter the cell was cooled. The carbonaceous products assembled within the solidified salt pool and deposited onto the steel surface were washed with distilled water and investigated by SEM/EDX. Parameters varied in the experimental program were the additions of $\mathrm{CaO}(0.5 \mathrm{~mol} . \%)$ and/or $\mathrm{Na}_{2} \mathrm{CO}_{3}(2.0 \mathrm{~mol} . \%)$ to the $\mathrm{CaCl}_{2}$ melt.

The first explanation that Abbasloo et al. put forward for the formation of nanocarbon in their electrolytic cell presupposes the intercalation of

(Received June 18, 2020; accepted August 21, 2020;

published online September 8, 2020)
$\mathrm{Ca}^{2+}$ ions into the anodically polarized graphite and the subsequent decomposition of the intercalated graphite.

However, this notion is based on a misunderstanding of the fundamentals of molten salt electrochemistry. It was indeed observed experimentally in 1995 that a melt of $\mathrm{LiCl}$ can react with cathodically polarized graphite in such a way that the graphite is converted into a range of nanocarbons. ${ }^{2}$ This finding was later rationalized through the intercalation of $\mathrm{Li}^{+}$, and equally $\mathrm{Na}^{+}$, ions into the cathodically polarized graphite. ${ }^{3,4}$ This leads to the fast build-up of mechanical stress inside the graphite body, the exfoliation and detachment of graphene sheets, and their geometric rearrangement within the melt. In the meantime, the process has been optimized with respect to carbon nanotube preparation in both $\mathrm{NaCl}$ and $\mathrm{LiCl}$ melts, ${ }^{5,6}$ and it has been shown that minor additions of $\mathrm{CaCl}_{2}$ to the melt can be allowed. ${ }^{7}$ The overall cathode reaction can be expressed as follows $(\mathrm{Me}=\mathrm{Li}, \mathrm{Na}){ }^{6}$

$$
\mathrm{Me}^{+}+e^{-}+x \mathrm{C}=\mathrm{MeC}_{x}
$$

The above representations make clear that the intercalation process relies on the reduction of metal cations from a salt melt at graphite that is cathodically polarized. In contrast, Abbasloo et al. postulate that $\mathrm{Ca}$ be intercalated into graphite that is anodically polarized. More specifically, they assume that a small amount of $\mathrm{Ca}$ is formed at the steel cathode and dissolves into the $\mathrm{CaCl}_{2}$ melt, that the dissolved $\mathrm{Ca}$ then loses two electrons at the graphite anode and forms $\mathrm{Ca}^{2+}$ cations, and that these $\mathrm{Ca}^{2+}$ cations then intercalate into the graphite anode. However, the intercalation of an aliovalent cation into an anode is physically impossible. Notably, the authors did not present any experimental evidence for their bold hypothesis. This 
could have been done by quenching the cell, breaking open the graphite anode, and testing for the presence of $\mathrm{Ca}$ inside.* Instead, they refer to the known existence of $\mathrm{Ca}$ stage compounds in graphite. $^{9,10}$ These are, however, formed in purely chemical reactions at much lower temperatures and only involve the incorporation of small amounts of $\mathrm{Ca}$ into the graphite. Overall, the idea of intercalating a cation into an anode should be dismissed.

The second explanation that Abbasloo et al. provide for the formation of nanocarbon in their cell is based on the reduction of the $\mathrm{CO}_{2}$ gas fed into the $\mathrm{CaCl}_{2}$ melt and the deposition of the carbon released from the $\mathrm{CO}_{2}$ onto the cathode surface.

This route of forming nanocarbon is well established in the field of molten salt electrochemistry. It was indeed observed experimentally as early as 1870 that the electrolysis of $\mathrm{CO}_{3}{ }^{2-}$ ions in a $\mathrm{CaCl}_{2}$ melt leads to the release of elemental carbon at the cathode. ${ }^{11}$ This finding was then substantiated in an in-depth investigation from $1966 .{ }^{12}$ Abbasloo et al., while acknowledging the latter study, ${ }^{* *}$ have tried to interpret their results further and have proposed various reaction paths. One option is that the $\mathrm{CO}_{2}$ dissolved in the $\mathrm{CaCl}_{2}$ melt is reduced directly at the cathode.

$$
\mathrm{CO}_{2}+4 e^{-}=\mathrm{C}+2 \mathrm{O}^{2-}
$$

It is furthermore discussed that the $\mathrm{CO}_{2}$ can react with $\mathrm{O}^{2-}$ ions in the melt to form $\mathrm{CO}_{3}{ }^{2-}$ ions and that these are then reduced at the cathode.

$$
\begin{gathered}
\mathrm{CO}_{2}+\mathrm{O}^{2-}=\mathrm{CO}_{3}^{2-} \\
\mathrm{CO}_{3}^{2-}+4 e^{-}=\mathrm{C}+3 \mathrm{O}^{2-}
\end{gathered}
$$

Another option is that $\mathrm{Ca}^{2+}$ ions are reduced at the cathode to $\mathrm{Ca}$ metal first and that the $\mathrm{Ca}$ then dissolves into the melt and reduces the $\mathrm{CO}_{2}$ or $\mathrm{CO}_{3}{ }^{2-}$.

$$
\begin{gathered}
\mathrm{Ca}^{2+}+2 e^{-}=\mathrm{Ca} \\
2 \mathrm{Ca}+\mathrm{CO}_{2}=\mathrm{C}+2 \mathrm{CaO} \\
2 \mathrm{Ca}+\mathrm{CO}_{3}^{2-}=\mathrm{C}+2 \mathrm{CaO}+\mathrm{O}^{2-}
\end{gathered}
$$

Regarding the mechanism expressed by Eqs. 3 and 4, Abbasloo et al. portray it as a key result that the presence of $\mathrm{CaO}$, either added directly or formed indirectly from added $\mathrm{Na}_{2} \mathrm{CO}_{3}$, increases the amount of nanocarbon formed in the process.

\footnotetext{
*In the electrolysis of molten $\mathrm{CaCl}_{2}$, using graphite as the anode, the only anode reaction is the release of $\mathrm{Cl}_{2}$. There is no change in the volume or the morphology of the graphite body that might point to a reaction with $\mathrm{Ca}{ }^{8}$

**Abbasloo et al. erroneously attribute the publication by Ingram et al. ${ }^{12}$ to the year 1996 .
}

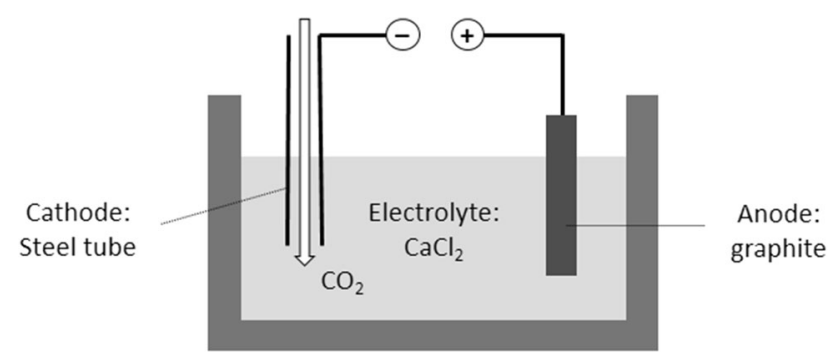

Fig. 1. Sketch of the experimental set-up used in the study by Abbasloo et al.

However, this claim of novelty is not justified. Instead, it is known from detailed reports from 1986 and 1990 that the amount of $\mathrm{CaO}$ dissolved in the $\mathrm{CaCl}_{2}$ melt determines the solubility of $\mathrm{CO}_{2} \cdot{ }^{13,14}$ The experimental observation is hence only a confirmation of established facts.

Regarding the mechanism expressed by Eqs. 5, 6, and 7, Abbasloo et al. argue that the applied voltage of $3.0 \mathrm{~V}$ is below the decomposition voltage of $\mathrm{CaCl}_{2}$ of $3.1 \mathrm{~V}$ but above the decomposition voltage of $\mathrm{CaO}$ of $2.7 \mathrm{~V}$. Therefore, any $\mathrm{CaO}$ in the melt, either present as an impurity or as a deliberate addition, is thought to give rise to the formation of $\mathrm{Ca}$ at the cathode. However, this assessment is not strict. The decomposition voltage of $2.7 \mathrm{~V}$ concerns the decomposition of $\mathrm{CaO}$ into $\mathrm{Ca}$ and $\mathrm{O}_{2}$, but the given cell has a graphite anode and so the actual decomposition is into $\mathrm{Ca}$ and $\mathrm{CO} / \mathrm{CO}_{2}$. As such, the formation of $\mathrm{CO} / \mathrm{CO}_{2}$ is thermodynamically favored over the formation of $\mathrm{O}_{2}$ by about $1 \mathrm{~V}$. However, the formation of $\mathrm{CO} / \mathrm{CO}_{2}$ at a graphite anode has a substantial overpotential that can readily exceed $1 \mathrm{~V}$ for a total applied voltage on the order of $3.0 \mathrm{~V} .^{15}$ The overpotential is a kinetic quantity, depending on the reactivity of and the current density at the anode, and so its precise value is unknown. Consequently, no reliable a priori statement can be made as to whether the electrolysis of $\mathrm{CaO}$ into $\mathrm{Ca}$ and $\mathrm{CO} / \mathrm{CO}_{2}$ can take place to an appreciable extent in the twoterminal cell used, and the experiments without added $\mathrm{CO}_{3}{ }^{2-}$ ions did indeed yield only a slight degree of anodic graphite consumption. It is thus possible that the graphite consumption observed in the other experiments occurred primarily as the counterreaction to Eqs. 2 and 4, but not to Eq. 5 .

As a minor point, the addition of $\mathrm{Na}_{2} \mathrm{CaO}_{3}$ to the $\mathrm{CaCl}_{2}$ melt does not help elucidate the reaction mechanism because this introduces a new species to the system. It would have been more methodical to admix $\mathrm{CaCO}_{3}$ instead.

In conclusion, Abbasloo et al. have deliberated two possible pathways for the formation of nanocarbon via the electrolysis of a $\mathrm{CaCl}_{2}$ melt into which $\mathrm{CO}_{2}$ gas is fed. As shown, one is outright impossible and the other is well established. Moreover, and even though a multitude of results have been collected, the study lacks a clear takeaway message. This is because the authors vacillate randomly 
between their two explanations throughout the discussion, and with one of them invalid, no clear correlations can be recognized for the other. Overall, the study has no academic rigor and ought to be disregarded.

\section{CONFLICT OF INTEREST}

The author declares that he has no conflict of interest.

\section{REFERENCES}

1. S. Abbasloo, M. Ojaghi-Ilkhchi, and M. Mozammel, JOM 71, 2103 (2019).

2. W.K. Hsu, J.P. Hare, M. Terrones, H.W. Kroto, D.R.M. Walton, and P.J.F. Harris, Nature 377, 687 (1995).

3. G.Z. Chen, X.D. Fan, A. Luget, M.S.P. Shaffer, D.J. Fray, and A.H. Windle, J. Electroanal. Chem. 446, 1 (1998).

4. J. Sytchev and G. Kaptay, Electrochim. Acta 54, 6725 (2009).

5. I.A. Kinloch, G.Z. Chen, J. Howes, C. Boothroyd, C. Singh, D.J. Fray, and A.H. Windle, Carbon 41, 1127 (2003).
6. C. Schwandt, A.T. Dimitrov, and D.J. Fray, J. Electroanal. Chem. 647, 150 (2010).

7. G. Kaptay, I. Sytchev, J. Miklósi, P. Nagy, P. Póczik, K. Papp, and E. Kálmán, Progress in Molten Salt Chemistry 1, ed. R.W. Berg and H.A. Hjuler (Amsterdam: Elsevier, 2000), p. 257.

8. C. Schwandt and D.J. Fray, Electrochim. Acta 51, 66 (2005).

9. S. Pruvost, C. Hérold, A. Hérold, and P. Lagrange, Eur. J. Inorg. Chem. 2004, 1661 (2004).

10. N. Emery, C. Hérold, and P. Lagrange, J. Solid State Chem. 178, 2947 (2005).

11. P. Burckhard, Z. Chem. 13, 212 (1870).

12. M.D. Ingram, B. Baron, and G.J. Janz, Electrochim. Acta 11, 1629 (1966).

13. M. Maeda and A. McLean, Iron Steelmak. 13, 61 (1986).

14. G.J. Kipouros and R.A. Sharma, J. Electrochem. Soc. 137, 3333 (1990).

15. C. Schwandt, D.T.L. Alexander, and D.J. Fray, Electrochim. Acta 54, 3819 (2009).

Publisher's Note Springer Nature remains neutral with regard to jurisdictional claims in published maps and institutional affiliations. 